\title{
Life Cycle In Organizations: A Stationery Shop Case Study
}

Dr. Lorena Hernández von Wobeser, Universidad del Caribe, México

\begin{abstract}
This teaching case reviews the basis of Life Cycle Model in order to understand the transitional stages in organizations. It focuses particularly on Adizes ten stages model. The single case presented here helps us to reflect on life cycle of a micro sized business in Cancún, México. As narrated by her owner; the micro-sized business has passes three stages that she calls: the beginning, the expansion and the foundation stages. This case study is suggested for undergraduate students in managerial or organizational studies programs.
\end{abstract}

Keywords: Organizational Life Cycle; Organizational survival; Organizational failure; Micro-sized Enterprise

\section{INTRODUCTION}

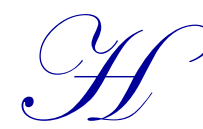
igh mortality in organizations is a trend topic in academic, managerial and official (government) documents, particularly in the study of MSMEs (Micro, Small, Medium-Sized Enterprises). Different terminologies have been used to refer to this phenomenon:

- Opening of a business/ closure of a business

- Entrepreneurial failure/ entrepreneurial success

- Organizational mortality/ organizational survival

This terminology has been used by a large group of scholars to approach the study of the continuity or failure of a business (some of the authors use them indistinctly). The terminology most used in the study of this topic is 'Life Cycle Model' (organizational mortality/organizational survival). In the first section of this paper a theoretical discussion about the basis of Life Cycle Model is presented. Then, the author describes the story of the Stationery Shop Silvestre, as her owner Graciela Mendoza narrates. Finally, in the last section some teaching notes are suggested for undergraduate students in managerial or organizational studies programs.

\section{THEORETICAL OVERVIEW}

\section{Organizational Life Cycle Theory}

Life Cycle Model's authors study the transitional stages of organizations using terms borrowed from the biological science language. Terms applied to study different forms of life such as plants, animals and, of course the human being, are used to describe organizational process; for example: 'organizational birth, 'organizational survival' and 'organizational mortality'. Life Cycle Model treats organizations as if they were some kind of living being.

According to Ionescu y Negrusa (2007), Kenneth Boulding was the first author who in 1950 used the concept 'life cycle' in the organizational cycle. "Since that time, discussion of the organizational life cycle have taken place within many disciplines" (Ionescu y Negrusa, 2007: p. 5). A growing number of authors focused their interest in organizational life cycle for instance the work of "Chandler, 1962; Greiner, 1972; Galbraith, 1982; Churchill, 1983; Quinn and Cameron, 1983; Miller and Friesen, 1980, 1984; Smith, Mitchell and Summer, 1985; Dodge and Robbins, 1992; Hanks, Watson, Jensen and Chandler, 1993; Kazanjian, 1988; Beverland and Lockshin, 2001; Lester, Parnell and Carraher, 2003" (in Wang, p. 2). Some studies of life-cycle in organization are quantitative time-series analysis, while a broaden number of studies are case-oriented (Greiner, 1994: p. 2). 
Organization 'mortality rates' and 'survival rates' are two measures that were borrowed from both human demographical and biological populations' studies. Hannan and Freeman had studied mortality rates with the model they call Organizational Ecology; "An ecology of organizations seeks to understand how social conditions affect the rates at which new organizations and new organizational forms arise, the rates at which organizations change forms, and the rates at which organizations and forms die out" (Hannan \& Freeman, 1989: p. 7). They study the organizational behavior in populations of organizations (a number of organizations sharing an environment).

Summarizing, the common idea of Life Cycle authors is that organizations can be compared to life organisms (Lester and Parnell, 2005) and such organizations develop mainly through three stages: birth, youth and maturity or decline. "There is no debate as to the validity of applying the biological concept of life cycle to organizations. It is clear that organizations are at some point "born" (Tichy, 1980), they grow to one size or another (Mintzberg, 1979, 1989), and eventually they all "die" (Kimberly and Miles, 1980)" (Lester and Parnell, 2005: p. 203). However, there is debate about the number of stages that can be used to describe an organizational life cycle (Lester and Parnell, 2005). There are variations in the number proposed (from tree to ten stages). Queen and Cameron (1983) mention at last nine different models of organizational life cycles proposed (Nazzari and Foroughi, 2007). Wang quotes three of them:

- three stages (Smith, Mitchell, and Summer, 1985): inception, high growth, and maturity.

- five stages (Miller and Friesen, 1984): birth, growth, maturity, revival, and decline.

- ten stages (Adizes, 1989): courtship, infancy, go-go, adolescence, prime, stable, aristocracy, early bureaucracy, bureaucracy and death.

Of course, not all organizations pass though all stages. For example, organizations do not have to grow old before they decline or die (Ionescu and Negrusa, 2007). Adizes explains the early decline of organizations in his graphic model. Exhibit A shows the Adizes Life Cycle Model which contains the ten stages of organizations, and their five possible declining phases (Affair, Infant Mortality, Founder or Family Trap, Unfilled Entrepreneur and Premature Aging).

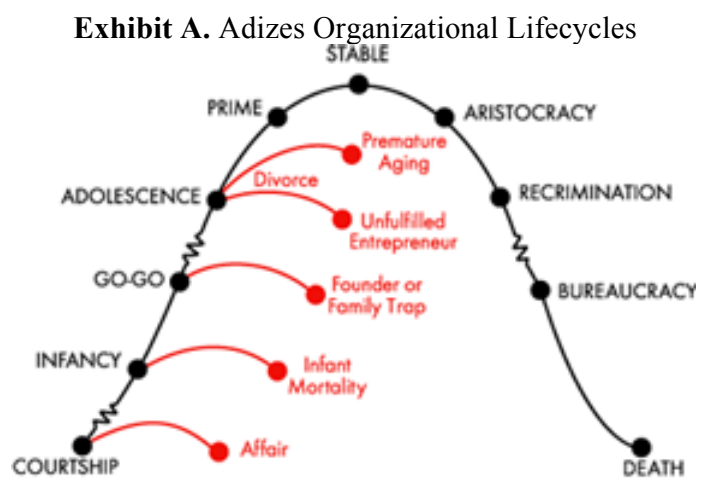

\section{Adizes Organizational Lifecycles}

Source: Adizes Graduate School, retrieved from http://www.adizesgraduateschool.org/adizes_seminars.html

Adizes' model is perhaps, one of the most complete life-cycle organization models. Some of the terms require further explanation:

- Courtship: the company is not yet born. The preliminary goal is to build founder's enthusiasm and commitment to his dream.

- Infancy: like a real baby, infant organizations need two things to survive: 1) periodic infusion of milk (operating capital), and 2) the unconditional love of their parents (Founders).

- Go-go: go-go Companies are like babies that have just learned to walk. They can move quickly and everything looks interesting. They have successful product and service, rapidly growing sales and strong cash flow. 
- Adolescence: the company must find a life apart from that provided by its founder, decentralization of authority and change the leadership from the owner to a professional management.

- Prime: is the optimal position on the lifecycle, where the organization finally achieves a balance between control and flexibility.

- Stability: companies have started to lose their vitality and are aging. The company is strong, but is starting to lose flexibility.

- Aristocracy: the effects of decline start to become more obvious. It has neglected to pursue long-term opportunities, and the company's focus becomes increasingly short-term. For the most part, its goals are financially-oriented and low-risk.

- Recrimination: people focus on who caused the problem, rather than what to do about the problem. Problems bet personalized. Paranoia freezes the organization.

- Bureaucracy: although it should be dead, the company is kept alive by artificial life support. A company is largely incapable of getting sufficient resources to sustain itself. The bureaucracy organization has many systems and rules and runs on ritual, not reason.

- Death: death occurs when no one remains committed to sustaining the organization (Adizes in Nazzari y Foroughi, 2007: p. 3).

Once the Life Cycle Model main ideas have been reviewed, the Silvestre Stationery Shop business case is presented.

\section{CASE SCENARIO}

\section{Silvestre Stationery Shop}

This case study was constructed as proposed by Yin, (2009) in a single case approach. The data of the case was collected by using different methodological tools such as: a) longitudinal observation of the business; b) a survey applied to its owner; and c) a semi-structured interview.

Stationery Shop Silvestre is a micro sized business located in the non-touristic area of Cancun, México. The owner, Graciela M. - a sixty year-old woman with basic education- opened the business in 2005. Graciela M. narrates her reasons for starting a business: a better future for her children, the only alternative against the difficulty to get a job (being an elderly woman), the hope for a better life, and being able to have an independent old age. A single mother, she raised five children herself. Her children's childhood was very difficult; a big poor family struggling to survive. Graciela remembers her children studying for the elementary school exams by candlelight since they had no money to pay for electricity. Before starting a business Graciela used to work as an independent seamstress. In this context, the entrepreneurship was a tangible possibility for changing the present and future of Graciela's family. "My grandchildren will not suffer what my children did!" Graciela points.

Graciela narrates (and conceptualized) the life of the Stationery Shop Silvestre in three stages named by her as: the Beginning, the Expansion and the Foundation. The "Beginning stage" was difficult but exciting. With less than 600 dollars ( $\$ 10,000$ Mexican pesos) and a property that shares room with a shop, she opened the Stationery Shop Silvestre. "My daughter Sofia told me: - let's open a Stationery Shop-. We were in a group saving pool, and each of us contributed with 5,000 pesos. So we had 10,000 pesos and we went shopping... What a surprise, it wasn't enough merchandise for the business! The shop shelves looked empty!"(Graciela). Despite the difficulty Graciela states: "I felt fulfilled, it was as if I were living a dream which had come true" (Graciela).

During the "Expansion stage", Graciela and her daughter Sofía reinvested their savings from the business to stock up. Little by little, the business conditions improved. As pointed by Graciela: "A year and a half had passed, the shop started looking much better, and it was as if the business flirted with me!" But shortly, Sofía, the young daughter got pregnant and Graciela told her: "you can be the sole owner of the Stationary Shop, we can move the shop to your house and I'll start over again with another business", . After moving the Shop, Graciela and Natalia, a youngest daughter got a loan. After a year of preparation they opened a second Stationary Shop which included a

\footnotetext{
${ }^{1}$ In México many families with micro-sized business raise their kids in home-business shared area. 
cybercafé. "So we started buying two computers, then we began growing little by little until we acquire twelve computers". The main clients of the business were neighbors who were studying elementary and high school and needed both computers and stationary products.

Nowadays, in the "Foundation stage" Graciela evaluates her business which is in a difficult stable moment: "we are surviving thanks to the school period, our main income comes from small sales: molding clay, cardboards, pencils, stuff like that." With a second loan to pay, small profit earnings, high taxes and long work journeys (13 hours: from 9 am to $11 \mathrm{pm}$ ); Stationary Shop and Cyber Silvestre subsists.

\section{CONCLUSION}

The biological influenced Life Cycle Model for understanding organizations has allowed the emergence of different stage models proposals and theories about what makes organizations change between stages. One of the implications of the uses of this metaphor (or model) is that includes a "pro-life position" in organizations. From this point of view, it is desirable a business is born, grows and even reproduces (via franchise or subsidiary). But the common assumption that enterprises (and- especially small businesses-) are expected to develop and grow has also its limitations. Cleri (2007) argues that it is common to think that small businesses are the starting point in the "evolutionary specie of the enterprise". He thinks this is a fallacy that emerges when organizations are assimilated to human life since not all enterprises follow this trajectory; the majority, it remains small with the passing of time (Cleri, 2007: pp. 36-37). It also could be possible that an enterprise would be born medium- sized or even, big (they aren't necessarily born small). This metaphor does not take into account the businesses that survive in an unsuccessful way, even for years; or businesses that close their doors in a successful way, for example when owners decide to close the business during financial peak because they are just too tired to continue. Finally this metaphor neither takes into account the cases where it is more convenient to stay small (because the owner can't assimilate the growth or because there is no a market for the product/service).

\section{AUTHOR INFORMATION}

Lorena Hernández von Wobeser is a professor of Organizational Psychology at Universidad del Caribe, CancunMexico. She holds a Ph.D. in Organization Studies by Universidad Autónoma Metropolitana and a Master's degree in Business from ITESM. She also has a combination of academic and business experience. Contact with the author is encouraged and welcomed. She can be reached at lhvon@ucaribe.edu.mx

\section{REFERENCES}

Adizes, I. (1989) Corporate Life Cycles: How and Why Corporations Grow and Die an What to Do About It. Englewood-Cliffs, NJ: Prentince Hall.

Cleri, C. (2007). El libro de las PYMES. Buenos Aires: Granica.

Greiner, L. (1994). Evolution and Revolution as Organizations Grow. En L. Mainiero, \& C. Tromley, Developing Managerial Skills in Organizational Behavior: Exercises, Cases, and Readings (pp. 322-329). Englewood Cliffs, NJ: Prentice Hall.

Ionescu, G., \& Negrusa, A. L. (2007). The Study about Organizational Life Cycle Models. Review of International Comparative Management, 8 (4), 5-17.

Hannan, M., \& Freeman, J. (1989). Organizational Ecology. London: Harvard University Press.

Lester, D., \& Parnell, J. (2005). The Progression of Small and Medium-Sized Entreprises (SME) through the organizational life cycle. International Journal of Orgaizational Analysis , 202-215.

Nazzari, S., \& Foroughi, H. (2007). Organization's Changes Through its Lifecycle; a System Dyaics Approach. Obtained by System Dynamics Society conference: www.systemdynamics.org Queen, R. and Cameron, K. (1983) Organizational lifecycle and shifting criteria for effectiveness. Management Science. Vol. 9. No. 1.

Wang, K.-c. (s.f.). Business Life Cycle and Five Elements Theory. 1-14.

Yin, R. (2009). Case Study Research. Design and Methods. United States of America: Sage. 


\section{DISCUSSION QUESTIONS}

Learning objectives are:

- To discuss the contributions and limitations of the Life Cycle theoretical model.

- To illustrate the transitional stages of an organization through a real-life example.

Questions:

1. Can the three stages conceptualized by Graciela for her own Stationery Shop (the beginning, the expansion and the foundation) be related to some of the stages proposed by Adizes? If so, how?

2. From your point of view, does the Stationery Shop Silvestre could enter into a declining phase (as proposed by Adizes)? If so, which declining phase could be a danger for this business?

3. How do you imagine the future of the Stationery Shop Silvestre? Will it stay in the same stage or will it change to another Adizes' stage?

4. Based on the story of the Stationery Shop Silvestre, can the terms "organizational survival" and "organizational success" be used indistinctly? Why?

- Which could be the possible contributions and limitations of this theoretical model for the understanding of Mexican micro-sized businesses reality?

5. Use Adizes ten lifecycle model to discuss the current stage of some international companies such as:

- The Facebook Company

- Xerox Company 


\section{NOTES}

